\title{
Peningkatan Kinerja Biaya Berbasis Value Engineering Pada Proyek Green Hospital
}

\author{
Ali Imron', Albert Eddy Husin ${ }^{1, *}$ \\ Program Studi Magister Teknik Sipil, Universitas Mercu Buana ${ }^{1}$ \\ Koresponden*,Email:albert_eddy@mercubuana.ac.id
}

\begin{tabular}{|c|c|c|}
\hline & Info Artikel & Abstract \\
\hline Diajukan & 04 Mei 2021 & In Hospital Work with the Green concept, there are several provisions that must be adhered to that \\
\hline Diperbaiki & 27 Juli 2021 & all processes, both the selected material, the method of implementation and the operation of the \\
\hline Disetujui & 27 Juli 2021 & $\begin{array}{l}\text { building must refer to the Green principle. By using the Value Engineering (VE) method and then } \\
\text { the Life Cycle Cost Analysis (LCCA), the researcher tries to apply the Green Hospital concept to } \\
\text { the project which is a case study but is still cost efficient even lower than the initial Bill of Quantity } \\
\text { (BOQ). For the effect of the two efficiency methods on the green hospital project, the researcher } \\
\text { gave a questionnaire to the stakeholders, the results of the questionnaire were collected, processed } \\
\text { and analyzed using SPSS Ver. 21.0. It turns out that the use of the VE and LCCA methods is very }\end{array}$ \\
\hline \multicolumn{2}{|c|}{$\begin{array}{l}\text { Keywords: Green Hospital, SPSS, Value } \\
\text { Engineering, Life Cycle Cost Analysis, Cost } \\
\text { Performance. }\end{array}$} & $\begin{array}{l}\text { influential in increasing cost performance. From the existing report, the LCCA method shows the } \\
\text { payback period for solar power plants with time }=9.64 \text { years } \approx 9 \text { years } 7 \text { months, hazardous waste } \\
\text { destruction with time }=4.28 \text { years } \approx 4 \text { years } 3 \text { months }\end{array}$ \\
\hline
\end{tabular}

Abstrak

Di Pekerjaan Rumah Sakit yang berkonsep Green, ada beberapa ketentuan yang harus dipatuhi bahwa semua proses baik material yang dipilih, metoda pelaksanaan maupun operasional bangunan harus mengacu pada kaidah Green. Dengan menggunakan metoda Value Engineering (VE) kemudian Life Cycle Cost Analysis (LCCA), peneliti mencoba menerapkan konsep Green Hospital pada proyek yang menjadi studi kasus namun tetap berbiaya efisien bahkan lebih rendah dari Rencana Anggaran Biaya (RAB) awal. Untuk mengetahui pengaruh kedua metoda efesiensi biaya terhadap proyek green hospital, peneliti menyebarkan kuesioner kepada para stakeholder , hasil dari kuesioner tersebut dikumpulkan, diolah dan dianalisis menggunakan SPSS Ver. 21.0. Ternyata bahwa penggunaan metoda VE dan LCCA ini sangat berpengaruh dalam meningkatkan kinerja biaya. Dari kesimpulan yang ada metoda LCCA menunjukkan pembayaran kembali (Payback Period) untuk Pembangkit

Kata kunci: Green Hospital,SPSS, Value Engineering, Life Cycle Cost Analysis, Kinerja Listrik Tenaga Surya dengan waktu $=9,64$ Tahun $\approx 9$ Tahun 7 Bulan, Pemusnah Limbah B3 dengan waktu $=4,28$ Tahun $\approx 4$ Tahun 3 Bulan.

kunci dalam peningkatan efisiensi energi di gedung-gedung [4].

Sektor konstruksi bertanggung jawab atas penggunaan sumber daya alam dan konsumsi energi yang berlebihan. Dilaporkan bahwa bangunan menghasilkan 36\% emisi $\mathrm{CO} 2$ [5]. Bangunan rumah sakit mengkonsumsi 73 miliar kilowatt -jam (kWh) listrik setiap tahun, berkontribusi pada fakta bahwa bangunan bertanggung jawab atas hampir 70\% dari total penggunaan listrik di Amerika Serikat [6].

Mengenai kinerja biaya saat ini, disimpulkan bahwa proyek bangunan hijau pada umumnya melebihi anggaran $(4,5 \%, 7 \%)$, yang lebih buruk daripada proyek bangunan tradisional [7]. Oleh karena itu, terdapat model insentif (I) potensial lainnya dalam penerapan green building, seperti Floor-to-Area Ratio (FAR), pengurangan pajak, dan percepatan proses perizinan [8].

Karena pentingnya desain berkelanjutan terus berkembang, menjadi semakin penting untuk mengembangkan metodologi yang mampu membantu desainer dalam menilai apa 
kah sebuah proyek berkelanjutan dan hemat biaya sambil tetap sukses sejajar dengan tujuan pemilik [9].

Dengan adanya penelitian ini diharapkan pembangunan rumah sakit dapat lebih disesuaikan dengan kebutuhan wajib untuk ketentuan Rumah Sakit Hijau. Rekayasa nilai telah digunakan sebagai metodologi untuk memberikan nilai tambah dan untuk meningkatkan hasil yang maksimal bagi pengembangan proyek dalam hal peningkatan kualitas, teknologi, dan inovasi [10].

Lingkup Green Hospital adalah:

Ada sejumlah fitur yang dapat membuat bangunan menjadi 'hijau/Green'. Ini termasuk (https://www.worldgbc.org/ what-green-building):

- Penggunaan energi, air, dan sumber daya lainnya secara efisien.

- Penggunaan energi terbarukan, seperti energi matahari.

- Langkah-langkah pengurangan polusi dan limbah, dan memungkinkan penggunaan kembali dan daur ulang.

- Kualitas udara lingkungan dalam ruangan yang baik.

- Penggunaan bahan yang tidak beracun, etis, dan berkelanjutan.

- Pertimbangan lingkungan dalam desain, konstruksi dan pengoperasian.

- Pertimbangan kualitas hidup penghuni dalam desain, konstruksi, dan pengoperasian.

- Desain yang memungkinkan adaptasi terhadap lingkungan yang berubah.

Bangunan apa pun bisa menjadi Green Building, baik itu rumah, kantor, sekolah, rumah sakit, pusat komunitas, atau jenis bangunan lainnya, asalkan menyertakan fitur yang tercantum di atas.

Variabel Green Hospital

$\begin{array}{lll}\begin{array}{l}\text { Main Factors } \\ \text { Stakeholder } \\ \text { Proyek }\end{array} & 1 & \begin{array}{c}\text { Sub Factors } \\ \text { Competence of project team } \\ \text { Competence of project } \\ \text { manager }\end{array} \\ & 3 & \begin{array}{l}\text { Competence of GB consultant } \\ \text { Competence of contractor }\end{array} \\ \text { Dukungan } & 4 & \text { Worker's experience and skill } \\ \text { Peraturan } & 6 & \text { Policies and regulations } \\ & 7 & \text { Government green awareness } \\ & 8 & \text { Water saving design } \\ \text { Dokumen } & 9 & \text { Energy saving design } \\ \text { Kontrak } & 10 & \text { Material saving design } \\ & 11 & \text { Tender Drawing } \\ & 12 & \text { Bill Of Quantity } \\ & 13 & \text { Technology specification }\end{array}$

LCCA (Lifecycle Cost Analysis) adalah metode pengoptimalan teknis dan ekonomis yang tujuan utamanya adalah mengidentifikasi dan memilih solusi yang menghasilkan pendapatan tertinggi selama masa layanannya atau, dengan kata lain, memiliki biaya siklus hidup terendah [11]. Analisis biaya siklus hidup menggunakan pendekatan Internal Rate of Return (IRR) dan Net Present Value (NPV) menegaskan bahwa pengembangan proyek Sunda Strait Bridge (SSB) dengan fungsi tambahan meningkatkan Tingkat Pengembalian Internal untuk keseluruhan proyek sebesar 7,56\% yang akan memberikan nilai NPV positif [12].

Dalam hal ini, peneliti menggunakan bantuan program analisis data SPSS (Statistical Products and Solution Services). Analisis ini digunakan untuk mengukur tingkat kedekatan hubungan antara semua variabel independen / X (independen) aspek Lifecycle Cost Analysis dan Value Engineering di Proyek Green Hospital (GH) dengan variabel dependen / Y (tergantung) Peningkatan Kinerja Biaya.

Suatu pengukuran dikatakan reliabel atau konsisten jika hasil pengukuran tersebut dapat menghasilkan yang serupa hasil jika digunakan lagi dalam keadaan yang sama [13].

\section{Analisis Data SPSS (Statistical Products And Solution Services)}

Ada banyak solusi perangkat lunak untuk masalah ini, tetapi salah satu yang paling terkenal adalah SPSS [14]. Proses analisis data akan menggunakan tool simulasi yaitu SPSS dengan ver. 21 disertai wawancara dan kuesioner maka akan di temukan hal-hal yang dominan dari beberapa variable dan sub faktornya yang mempengaruhi kinerja biaya yang ingin penulis teliti.Statistik SPSS menempatkan batasan pada struk tur file internal, tipe data, pemrosesan data, dan file yang cocok, yang bersama-sama sangat menyederhanakan pemrograman [15].

a. Menentukan Jumlah Responden

Mencari jumlah responden minimal menggunakan persamaan dibawah ini:

$$
Z(\mathcal{E} / 2)=\frac{1-\varepsilon}{2}=\frac{\mathrm{l}-0,05}{2}=0,475
$$

Diketahui:

$$
\begin{aligned}
& \mathrm{Z}=1,96 \text { Nilai yang diambil dari tabel distribusi } \mathrm{Z} \\
& \mathrm{P}=0,50 \text { Derajat variasi antar elemen populasi } \\
& \mathrm{E}=0,05 \text { Nilai sampel populasi terbatas } \\
& \mathrm{N}=43,0 \text { Jumlah sub faktor variabel } \\
& \mathrm{n}=\text { Jumlah responden minimal yang diperlukan }
\end{aligned}
$$

$$
\mathrm{m}=\frac{\mathrm{Z}^{2} \times \mathrm{P} \times(1-\mathrm{P})}{\varepsilon^{2}}=\frac{0,9600}{0,0025}=384,16
$$




$$
\mathrm{n}=\frac{\mathrm{m}}{1+\left[\frac{(\mathrm{m}-1)}{\mathrm{N}}\right]}=\frac{384,16}{9,91}=38,76
$$

Jadi jumlah responden minimal 39 orang yang datanya berdistribusi normal seperti terlihat pada Tabel 1.

Tabel 1. Jumlah Responden

\begin{tabular}{|c|c|c|c|}
\hline Jenis & Tersampaikan & Diterima & Presentase \\
\hline Kuesioner & Ke Responden & Kembali & Kembali \\
\hline Hardcopy & 80 set & 74 set & $92,50 \%$ \\
\hline
\end{tabular}

Alur analisis data seperti pada Gambar 1:

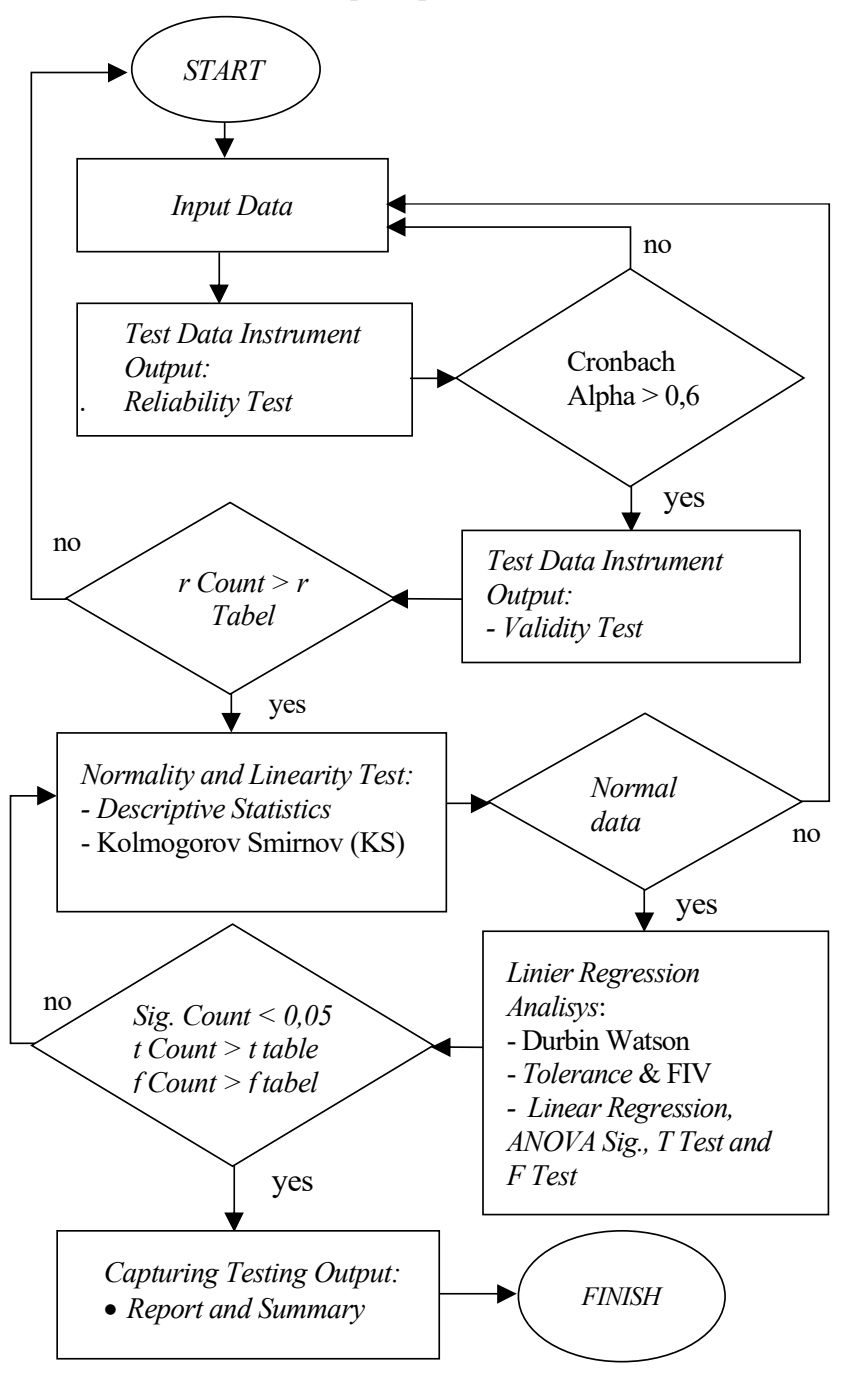

Gambar 1. Alur Analisis Data

Kita bisa menguji perbedaan antara dua mean dengan uji$t$ atau satu arah ANOVA, dan kedua tes tersebut secara mate- matis setara [16].

b. Analisis Regresi Linier,pengaruh variabel X secara parsial terhadap Y (Uji T)

Analisis data regresi liniernya dengan menjalankan SPSS yaitu:Klik Analyze $>$ Regression $>$ Linier $>$ Dep/Indep X1, $\mathrm{X} 2$,X3 dan $\mathrm{Y}>$ Statistic $>$ Plot $<$ Save $<$ OK, hasilnya seperti terlihat pada Tabel 2.

Tabel 2. Uji T

\begin{tabular}{|c|c|c|c|c|c|c|}
\hline \multicolumn{7}{|c|}{ Coefficients $^{\mathrm{a}}$} \\
\hline & \multirow{2}{*}{ Model } & \multicolumn{2}{|c|}{$\begin{array}{l}\text { Unstandardized } \\
\text { Coefficients }\end{array}$} & \multirow{2}{*}{$\begin{array}{c}\text { Standardized } \\
\text { Coefficients } \\
\text { Beta }\end{array}$} & \multirow[t]{2}{*}{$\mathrm{t}$} & \multirow[t]{2}{*}{ Sig. } \\
\hline & & B & $\begin{array}{l}\text { Std. } \\
\text { Error }\end{array}$ & & & \\
\hline \multirow{5}{*}{1} & (Constant) & 5.984 & 2.741 & & 2.183 & 0.033 \\
\hline & Green Hospital & 0.106 & 0.037 & 0.276 & 2.869 & 0.006 \\
\hline & Lifecycle Cost & 0.112 & 0.051 & 0.232 & 2.193 & 0.032 \\
\hline & Value & 0.141 & 0.035 & 0.435 & 4.018 & 0.000 \\
\hline & Engineering & & & & & \\
\hline
\end{tabular}

a. Dependent Variable: Cost Perform

Masukkan koefisien angka dari kolom B dari Tabel 2 ke persamaan :

$$
\mathrm{Y}=5,984+0,106 \mathrm{X} 1+0,112 \mathrm{X} 2+0,141 \mathrm{X} 3
$$

Uji t dikenal dengan uji parsial, yaitu untuk menguji bagaimana pengaruh masing-masing variabel bebasnya secara sendiri-sendiri terhadap variabel terikatnya.

Sebagai dasar pengambilan keputusan dari uji $\mathrm{T}$ tersebut dengan membandingkan $\mathrm{t}_{\text {hitung }}$ dengan $\mathrm{t}_{\text {tabel }}$ :

Variabel X1 (Green Hospital) berpengaruh secara positif dan signifikan terhadap $\mathrm{Y}$ hal ini digambarkan dari sig. (X1) $0,006<0,05$, Nilai Koordinat $\mathrm{t}$ table $=\mathrm{t}(\mathrm{a} / 2 ; \mathrm{n}-\mathrm{k}-1)=\mathrm{t}$ $(0.05 / 2 ; 69-3-1)=\mathrm{t}(0,025 ; 65)$, Lihat tabel bahwa $\mathrm{t}_{\text {table }}=$ 1,$997 ; \mathrm{t}_{\text {hitung }}=2,869$, Nilai $\mathrm{t}_{\text {hitung }}=2,869>1,997$, maka $\mathrm{H} 0$ ditolak dan $\mathrm{H} 1$ diterima.

Variabel X2 (Lifecycle Cost) berpengaruh secara positif dan signifikan terhadap $\mathrm{Y}$ hal ini digambarkan dari sig. (X2) $0,032<0,05$, Nilai Koordinat $\mathrm{t}$ table $=\mathrm{t}(\mathrm{a} / 2 ; \mathrm{n}-\mathrm{k}-1)=\mathrm{t}$ $(0.05 / 2 ; 69-3-1)=\mathrm{t}(0,025 ; 65)$, Lihat tabel bahwa $\mathrm{t}_{\text {table }}=$ 1,$997 ; \mathrm{t}_{\text {hitung }}=2,193$, Nilai $\mathrm{t}_{\text {hitung }}=2,193>1,997$, maka H0 ditolak dan $\mathrm{H} 2$ diterima.

Variabel X3 (Value Engineering) berpengaruh secara positif dan signifikan terhadap $\mathrm{Y}$ hal ini digambarkan dari sig. (X3) $0,000<0,05$, Nilai Koordinat table $=\mathrm{t}(\mathrm{a} / 2 ; \mathrm{n}-\mathrm{k}-$ 1) $=\mathrm{t}(0.05 / 2 ; 69-3-1)=\mathrm{t}(0,025 ; 65)$, Lihat table $\mathrm{t}$ table $=$ 1,997; $\mathrm{t}$ hitung $=4,018$, Nilai $\mathrm{t}$ hitung $=4,018>1,997$, maka $\mathrm{H} 0$ ditolak dan $\mathrm{H} 3$ diterima.

c. Mean dan Rangking

Mencari mean dan rankingnya dengan menjalankan SP SS yaitu: Klik Analyze $>$ Scale $>$ Reliabilty Analysis $>$ Items 
(Var X1.1,X1,n;X2.1,X2.n;X3.1,X3.n dan Y1,Yn ke items) $>$ Statistic $>$ Centrang item dan mean $>$ Continue $>O K$, hasilnya seperti terlihat pada Tabel 3 .

Tabel 3. Tabel Mean dan Ranking

\begin{tabular}{|c|c|c|c|c|}
\hline Rangk & $\begin{array}{l}\text { No. } \\
\text { Urut }\end{array}$ & $\begin{array}{l}\text { Sub } \\
\text { Factors }\end{array}$ & Mean & Sub Faktor \\
\hline 1 & 2 & X1_02 & 4,68 & $\begin{array}{l}\text { Competence of project } \\
\text { manager }\end{array}$ \\
\hline 2 & 6 & X1_06 & 4,67 & Policies and regulations \\
\hline 3 & 14 & X2_01 & 4,48 & $\begin{array}{l}\text { Biaya Awal (Initial } \\
\text { Cost) }\end{array}$ \\
\hline 4 & 17 & X2_04 & 4,42 & $\begin{array}{l}\text { Biaya Operasional dan } \\
\text { Maintenance (OM Cost) }\end{array}$ \\
\hline 5 & 19 & X2_06 & 4,39 & Periode Analisa (n) \\
\hline 6 & 22 & X2_09 & 4,33 & $\begin{array}{l}\text { Moddeling tanpa nilai } \\
\text { sisa }\end{array}$ \\
\hline 7 & 24 & X3_01 & 4,29 & $\begin{array}{l}\text { Pemilihan alternatif } \\
\text { material yang tepat }\end{array}$ \\
\hline 8 & 28 & X3_05 & 4,19 & $\begin{array}{l}\text { Adanya Tim VE yang } \\
\text { multidisplin }\end{array}$ \\
\hline 9 & 32 & X3_09 & 4,17 & $\begin{array}{l}\text { Input informasi dan } \\
\text { komunikasi sebaik- } \\
\text { baiknya }\end{array}$ \\
\hline 10 & 34 & X3_11 & 4,16 & Fungsi primer \\
\hline
\end{tabular}

Berdasarkan peringkat penelitian dan kuisioner yang telah dilakukan, bahwa setiap perencanaan biaya, metode kerja dan spesifikasi material harus dicek kembali apakah sudah memenuhi green concept sebelumnya oleh tim yang dipimpin oleh project manager yang berkompeten di bidangnya untuk mewujudkan konsep hijau.

10 kompetensi inti manajer proyek (diperlukan untuk kinerja superior mereka) terdiri dari kemampuan kelompok, ke mahiran bahasa, meningkatkan keragaman, toleransi stres (manajemen), fleksibilitas, membangun hubungan, kepemimpinan, menjaga ketertiban, orientasi pencapaian, dan memahami orang lain [17].

\section{Hasil Penelitian}

Bangunan hijau ditekankan di seluruh siklus hidup bangunan. Termasuk produksi bahan bangunan, perencanaan, desain, konstruksi, operasi dan pemeliharaan dan pemindahan, daur ulang seluruh proses, semua tautan dapat menjadi penggunaan yang efisien dari sumber daya bangunan, penghematan lahan, hemat energi, dan hemat air [18]. Dibagian item pekerjaan studi kasus yang peneliti laksanakan, Lifecycle Cost Analysis (LCCA) ada dua item, yang termasuk dalam syarat bangunan Green, yaitu pengadaan energi panel surya photovoltaic (PV) dan pemusnah limbah B3 (Bahan Berbahaya dan Beracun). Keduanya merupakan syarat wajib bangunan Green yaitu Save Energy dan Waste Reduce, apalagi rumah sakit banyak menghasilkan limbah standard B3 dan infeksius yang perlu segera dimusnahkan. Pemasangan panel surya ini selain membantu meringankan beban lingkungan juga mampu menghemat pengeluaran biaya dari energi.

Lifecycle Cost Analysis (LCCA), yang merupakan persyaratan penting dalam pengadaan berkelanjutan, adalah alat utama untuk mengevaluasi efisiensi ekonomi dari total anggaran siklus hidup proyek bangunan [19]. Tujuan utama pada tingkat hierarki pertama yaitu bangunan rumah sakit hijau yang menyediakan ekologi, hemat air, hemat energi, pengurangan limbah dan lingkungan yang sehat bagi pasien dan staf [20]. LCCA deterministik adalah metodologi tradisional di mana pengguna menetapkan setiap variabel input (misalnya, masa pakai, periode analisis, tingkat diskonto, waktu dan biaya kegiatan pemeliharaan) nilai tetap yang biasanya didasarkan pada data historis dan penilaian pengguna [21].

Lifecycle Cost Analysis adalah Cost Breakdown Structure (CBS)--LCC Modelling Without Residual Value --Lifecycle Cost Analysis--Sensitivity Analysis-Efficiency [22].

Dalam perhitungan LCCA secara umum langkah-langkahnya adalah seperti terlihat pada Gambar 2 :

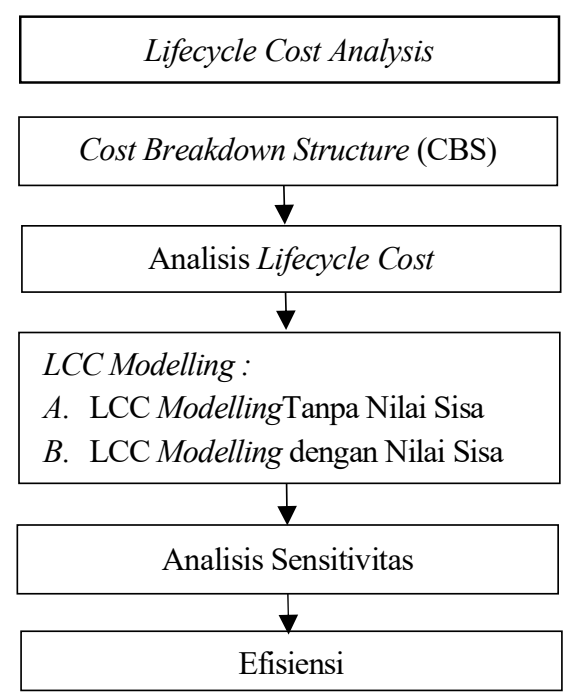

Gambar 2. Alur Analisis Data

(a) Cost Breakdown Structure

Meliputi biaya awal (initial cost), biaya konsumsi energi, biaya operator, biaya maintenance/consumable dan uji berkala/kalibrasi.

(b) Biaya awal (Initial Cost)

Biaya awal adalah biaya investasi awal dihitung beberapa tahun kedepan dengan bunga bank (\%). Jadi biaya 
pembelian awal material ditambahkan dengan interest bunga dan laju inflasi.

(c) Biaya energi (Energy Cost)

Biaya energi ini dihitung berdasarkan konsumsi listrik per Kwh/bulan dikalikan dengan tarif listrik dalam hal ini rumah sakit masuk dalam sarana pelayanan sosial. Energi yang dipakai di rumah sakit seperti untukpenerangan, tata udara, alat-alat kesehatan dan alat-alat sanitasi.

(d) Biaya penggantian (Replacement Cost)

Biaya ini dimasukkan karena dalam perjalanan umur material habis dan perlu diganti dengan yang baru, seperti yang umum adalah lampu-lampu, battery, kran-kran rusak, atap yang bocor, kaca pecah dll.

(e) Biaya Operasional dan Pemeliharaan (Operation and maintenance cost)

Biaya ini senantiasa muncul karena suatu benda perlu biaya pemeliharaan agas usia benda tersebut mencapai usia yang sudah direncanakan. Merupakan biaya pegawai dan kelengkapan pemeliharaan.

Dalam menghitung kapasitas produksi material penulis bersumber dari spesifikasi teknis yang dikeluarkan produsen dan secara teori dari berbagai sumber terdahulu. Setelah kapasitas produksi telah didapat kemudian berapa harga beli atau harga jual dari hasil produksinya tersebut.

Mengetahui juga apakah material tersebut ramah lingkungan, tidak meninggalkan jejak karbon, tidak menghasilkan limbah B3 dan tentu saja bisa menghemat pembiayaan operasional rumah sakit itu sendiri.

Pekerjaan yang akan diadakan ini sudah pasti menambah investasi, maka dalam penyajiannya harus betul-betul menjanjikan ke stakeholder bahwa material sebagai penambahan fungsi ini memberikan nilai tambah.

Penulis menjabarkan pekerjaan dalam diagram FAST (Function Analisys Sistem Technique) Sehingga dari diagram FAST akan terlihat seperti gambar diberikut ini menguraikan fungsinya dan di carikan alternatif bahan penggantinya seperti terlihat pada Gambar 3.

Mereka mengakui pihak terkait (pemilik proyek, perencana proyek, desainer, dan kontraktor) dalam proyek konstruksi bangunan hijau perlu merencanakan secara intensif aspek mana yang harus diperhatikan dalam proses perencanaan pra-proyek [23]. Value Engineering dilakukan untuk menghasilkan ide-ide inovatif yang berpotensi dapat diintegrasikan dalam proyek dengan menggunakan diagram Function Analysis System Technique (FAST) [24].

Model logis 'how-why' digunakan untuk mengindentifikasi, mengklasifikasikan, mengembangkan dan memilih fungsi itu dapat menciptakan nilai dan manfaat yang lebih besar bagi pengembangan proyek [24].
Prinsip pembangunan berkelanjutan di lingkungan binaan telah mendorong para peneliti untuk fokus pada selubung bangunan yang lebih efisien [25].Kinerja biaya adalah faktor ekonomi berdasarkan pemilihandari bahan fasad, yang meliputi konstruksi awal, penyewaaan, dan biaya pemindahan untuk setiap bahan yang dikumpulkan dari LCC [26].

Tahapan analisis fungsi Function Analisys Sistem Technique (FAST) mengacu kegiatan yang sudah diidentifikasi mempunyai pengaruh yang besar ke biaya proyek. Karena rumah sakit ini di rencanakan berkonsep green maka analisis fungsi fokus pada material yang belum ramah lingkungan di setiap item pekerjaan. Analisa fungsi pekerjaan disini bertujuan untuk mencari material yang belum ramah lingkungan dan sekaligus bisa dilaksanakan pengurangan biaya (reduction Cost) dengan menggunakan Technical FAST Diagram Before Additional Function

Fokus penelitian adalah analisa Value Engineering (VE) pada Tahap Pengembangan yaitu Lifecycle Cost Analysis ( $L$ CCA) dengan Technical FAST Diagram After Additional Function setelah ada penambahan nilai.

Banyak metoda yang dapat mendukung terciptanya konsep Green Hospital, namun karena keterbatasan waktu penelitian maka dibuat batasan penelitian yang diambil dalam penulisan seperti berikut:

1. Penelitian ini hanya mencakup konsumsi energi, sistem hemat energi dan instalasi energi mandiri instalasi pemusnah limbah B3.

2. Pembahasan pada penelitian ini hanya mencakup kinerja biaya proyek pembangunan Green Hospital.

Alasan pemilihan objek yang pertama: perancang dan pemasang sistem energi surya sering kali dihadapkan pada potensi permukaan pemasangan yang sudah pada arah dan kemiringan yang tidak dapat diubah, misalnya, pilihan di antara dua atau lebih area atap yang ada atau yang diusulkan, masing-masing dengan setidaknya akses matahari yang baik [27]. Penerapan sistem fotovoltaik (PV) di tempat memberikan potensi pengurangan tertinggi untuk emisi Gas Rumah Kaca (GRK) siklus hidup dan operasional total, dengan potensi pengurangan masing-masing 92\% hingga 100\% dan $48 \%$ hingga $66 \%$ [28].

Alasan pemilihan objek kedua adalah: "Limbah Perawatan Kesehatan" (HCW) atau "limbah biomedis (BMW)" termasuk limbah apa pun dihasilkan selama diagnosis, pengobatan atau imunisasi manusia atau hewan di rumah sakit, apotik, laboratorium, bank darah atau kedokteran hewan dan lembaga penelitian [29]. Dasar-dasar limbah B3 yang berkelanjutan meliputi a) Klasifikasi dan karakteristik sumber limbah B3, b) Regulasi yang mengatur limbah B3 program manajemen dan manajemen, c) Konsep "Lingkungan Audit," 
d) Konsep" Pencegahan Pencemaran ", e) Pengembangan sistem dan fasilitas pengelolaan limbah berbahaya, dan f) Terintegrasi berkelanjutan pengelolaan dan praktik limbah berbahaya [30].

Tahap Pengembangan; Lifecycle cost pada VE didefinisikan sebagai nilai saat ini yang mencakup keseluruhan biaya proyek meliputi biaya investasi awal, biaya oprasional, biaya kepemilikan dan nilai akhir proyek pada umur rencana yang ditentukan sehingga berfokus pada nilai untuk menentukan alternatif yang didefinisikan untuk menghasilkan fungsi dasar, maka keseluruhan harus dapat dibandingkan [31].

Dibagian item pekerjaan studi kasus yang peneliti laksanakan LCCA ada dua item, yang termasuk dalam syarat bangunan
Green, yaitu pengadaan energi panel surya photovoltaic $(P V)$ dan pemusnah limbah B3 (Bahan Berbahaya dan Beracun). Keduanya merupakan syarat wajib bangunan Green yaitu Save Energy dan Waste Reduce, apalagi rumah sakit banyak menghasilkan limbah standard B3 dan infeksius yang perlu segera dimusnahkan. Pemasangan panel surya ini selain membantu meringankan beban lingkungan juga mampu menghemat pengeluaran biaya dari energi.

Namun yang di fokuskan disini adalah analisis Value Engineering (VE) pada Tahap Pengembangan yaitu Lifecycle Cost Analysis (LCCA) dengan Technical FAST Diagram After Additional Function setelah ada penambahan nilai berikut ini:

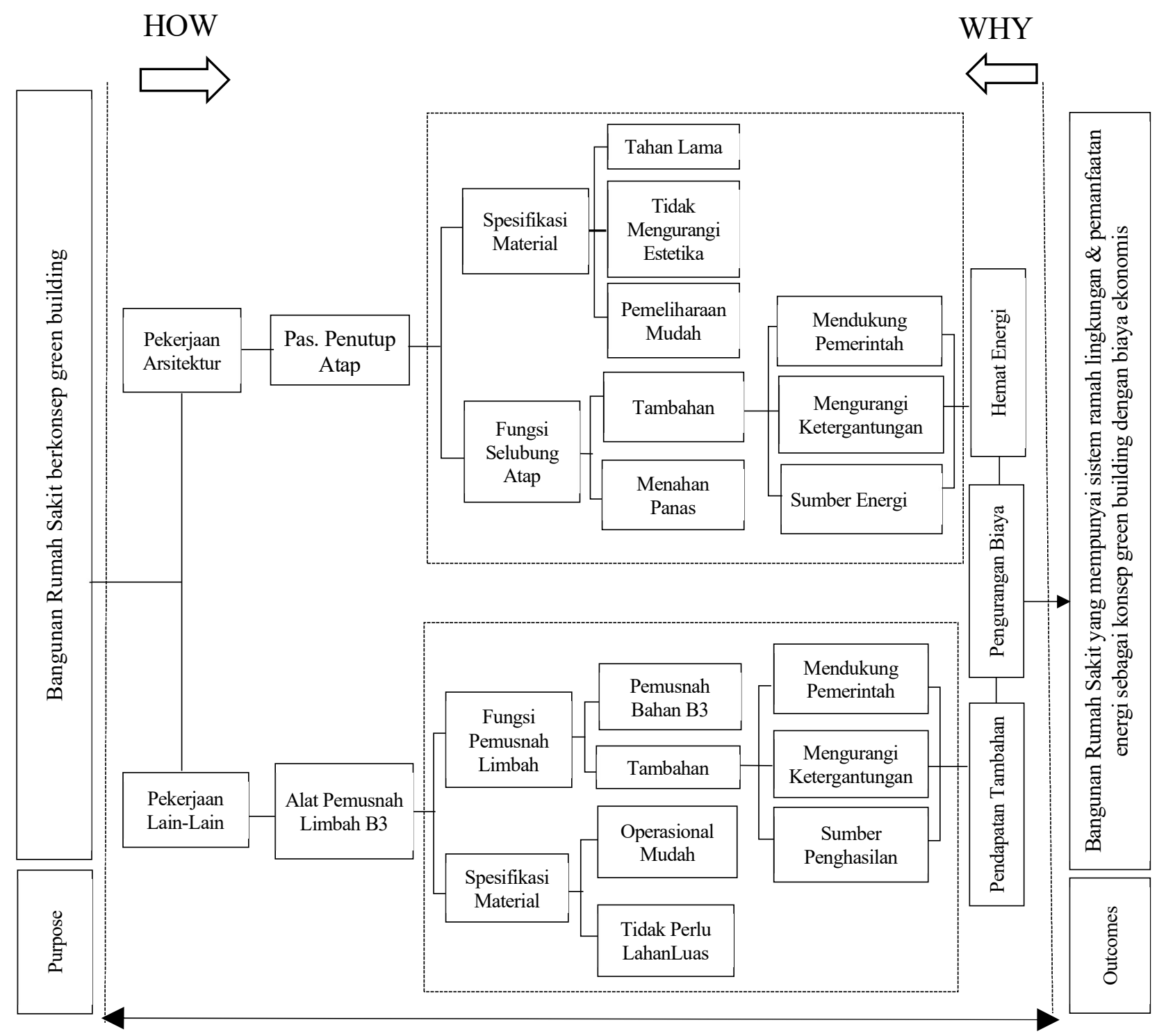

Gambar 3. Technical FAST Diagram After Additional Function 


\subsection{Pemanfaatan Selubung Atap}

Fungsi utama dari atap adalah menahan bangunan dari cuaca dan panas, fungsi tambahan dengan memanfaatkan luas atap dan konstruksinya kita bisa meletakan panel surya sebagai sumber energi terbarukan yang tidak meninggalkan jejak karbon, ramah lingkungan dan menghemat pengeluaran biaya energi ke pihak rumah sakit.

Di masa sekarang penyedia panel surya sudah banyak, tinggal kemauan dari para stakeholder untuk memanfaatkannya. Agar keraguan untuk investasi panel surya hilang dan berganti dengan semangat membantu lingkungan maka penulis mencoba memaparkan manfaat dari panel surya tersebut.

Luas atap yang tersedia akan ditutup dengan panel surya. Proses penutupan bergantung pada ukuran modul panel yang sudah ada. Dengan mengenal ukuran modul panel surya dan di- adaptasikan dengan model dan luas atap maka jumlah panel surya akan optima

(a) Analisa Output yang Dihasilkan Luasan Panel Surya

Data umum di bawah ini adalah tabel rata-rata radiasi matahari perbulan untuk daerah di indonesia yang diambil dari Badan Meterologi dan Geofisika Stasiun Klimatologi. Berdasarkan Data BMKG dari tiga tahun yang berbeda lama penyinaran mataharinya dalam satu hari diperkirakan 8 jam. Sehingga besarnya insolasi matahari dapat dihitung dengan mengalikan persentase penyinaran dengan lamanya penyinaran matahari. Seperti pada Tabel 4, dapat dilihat bahwa insolasi matahari setiap bulannya berbeda-beda.

Tabel 4. Rata-Rata Insolasi Matahari Per Bulan (Kwh/m2/day)

\begin{tabular}{|c|c|c|c|c|c|c|}
\hline \multirow{3}{*}{ Bulan } & \multicolumn{3}{|c|}{ Tahun } & \multirow{3}{*}{$\begin{array}{c}\text { Rata- } \\
\text { rata } \\
(\%)\end{array}$} & \multirow{3}{*}{$\begin{array}{l}\text { Bersinar } \\
\text { (Jam/hari) }\end{array}$} & \multirow{3}{*}{$\begin{array}{l}\text { Insolasi } \\
\text { matahari } \\
\text { (jam/hari) }\end{array}$} \\
\hline & 2014 & 2017 & 2018 & & & \\
\hline & $(\%)$ & $(\%)$ & $(\%)$ & & & \\
\hline Januari & 27 & 42 & 46 & 38,33 & 8 & 3,07 \\
\hline Februari & 31 & 54 & 74 & 53,00 & 8 & 4,24 \\
\hline Maret & 52 & 67 & 65 & 61,33 & 8 & 4,91 \\
\hline April & 51 & 69 & 76 & 65,33 & 8 & 5,23 \\
\hline Mei & 85 & 73 & 76 & 78,00 & 8 & 6,24 \\
\hline Juni & 64 & 68 & 76 & 69,33 & 8 & 5,55 \\
\hline Juli & 46 & 73 & 80 & 66,33 & 8 & 5,31 \\
\hline Agustus & 66 & 68 & 72 & 68,67 & 8 & 5,49 \\
\hline September & 71 & 72 & 72 & 71,67 & 8 & 5,73 \\
\hline Oktober & 71 & 69 & 63 & 67,67 & 8 & 5,41 \\
\hline November & 49 & 54 & 49 & 50,67 & 8 & 4,05 \\
\hline Desember & 31 & 57 & 49 & 45,67 & 8 & 3,65 \\
\hline
\end{tabular}

Sumber: Data BMKG

Dan insolasi matahari yang diambil adalah yang paling rendah yaitu sebesar 3,07 (jam/hari).
Daya output yang dihasilkan dari panel surya tersebut dapat dihitung berdasarkan spesifikasi panel surya yang digunakan, dan juga dengan menggunakan persamaan :

$\mathrm{P}_{\mathrm{G}}=\mathrm{A}_{\mathrm{G}} \times \mathrm{S} \times \mathrm{t} \times \eta$

Keterangan:

$\mathrm{A}=$ Luas panel surya

$\mathrm{S}=$ Rata-rata insolasi matahari

$\mathrm{t}=$ Lama penyinaran matahari

$\eta=$ Efisiensi panel surya

\section{(b) Pemilihan Panel Surya}

Indikator ini didistribusikan di antara enam faktor utama yang memengaruhi konsumsi energi: iklim, selubung bangunan, layanan bangunan dan sistem energi, operasi dan pemeliharaan bangunan, aktivitas dan perilaku penghuni, dan kualitas lingkungan dalam ruangan [32].

Dengan mempertimbangkan agar luas atap dapat diopti malkan maka dalam studi kasus ini dipilih 2 jenis modul panel surya yaitu :

Spesifikasi Panel Surya SP 100WP 18V Polycrystalline seperti terlihat pada Gambar 4:

Peak power (Pmax) $100 \mathrm{~W}$

Module efficiency $\quad 17.50 \%$

Dimensions $\quad 1000 \times 670 \times 30 \mathrm{~mm}$

Weight $\quad 7.5 \mathrm{~kg}$

Glass type High transmits, Low iron, $3.2 \mathrm{~mm}$

Frame Aluminium-alloy

STC: Irradiance $1000 \mathrm{~W} / \mathrm{m}^{2}$, Module temperature $25^{\circ} \mathrm{C}$, $\mathrm{AM}=1.5$

Spesifikasi Panel Surya SP 50WP 18V Polycrystalline seperti terlihat pada Gambar 5:

Peak power (Pmax) $50 \mathrm{~W}$

Module efficiency $\quad 17.50 \%$

Dimensions $\quad 540 \times 670 \times 30 \mathrm{~mm}$

Weight $\quad 3.8 \mathrm{~kg}$

Glass type High transmits, Low iron, $3.2 \mathrm{~mm}$

Frame Aluminium-alloy

STC: Irradiance $1000 \mathrm{~W} / \mathrm{m}^{2}$, Module temperature $25^{\circ} \mathrm{C}, \mathrm{AM}=1.5$
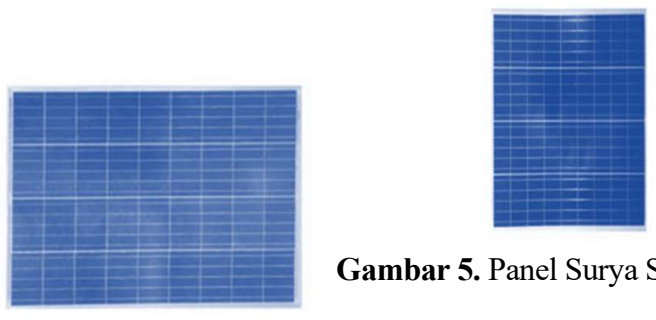

Gambar 5. Panel Surya SP 50WP

Gambar 4. Panel Surya SP 100WP 
Untuk mendapatkan biaya awal dari panel surya (initial cost), maka perlu di ketahui:

- Berat dan luas panel surya seperti pada Tabel 5.

- Harga panel surya dan biaya pasangnya per unit seperti terlihat padaTabel 6.

- Kapasitas total dari panel suryaseperti pada Tabel 7.

Tabel 5. Berat dan Luas Panel Surya

\begin{tabular}{llcccccc}
\hline & & \multicolumn{5}{c}{ Spesifikasi } \\
No & Jenis / Type & \multicolumn{4}{c}{ Dimensi } & Luas \\
& & $\begin{array}{c}\mathrm{P} \\
\mathrm{L}\end{array}$ & $\begin{array}{c}\mathrm{T} \\
(\mathrm{m})\end{array}$ & $\begin{array}{c}\text { Berat } \\
(\mathrm{m})\end{array}$ & $\begin{array}{c}\text { Panel } \\
(\mathrm{Kg})\end{array}$ \\
\hline & & $\left(\mathrm{m}^{2}\right)$ \\
\hline A & Model SP100-18P & 1,00 & 0,67 & 0,03 & 7,2 & 0,67 \\
\multirow{2}{*}{ B } & Model SP50-18P & 0,54 & 0,67 & 0,03 & 3,8 & 0,36 \\
\hline
\end{tabular}

Tabel 6. Harga Panel Surya Dan Biaya Pasangnya

\begin{tabular}{cccccc}
\hline \multicolumn{7}{c}{ Tabel 6. Harga Panel Surya Dan Biaya Pasangnya } \\
No. & Jenis / Type & $\begin{array}{c}\text { Maya } \\
\text { PV } \\
\text { PV }\end{array}$ & $\begin{array}{c}\text { 1 Watt } \\
\text { Peak } \\
\text { (Rp.) }\end{array}$ & $\begin{array}{c}\text { Harga 1 } \\
\text { Panel PV } \\
\text { (Rp.) }\end{array}$ & $\begin{array}{c}\text { 1 Set } \\
\text { gan PV } \\
\text { (Rp.) }\end{array}$ \\
\hline A & Model SP100-18P & 100 & 13.500 & 1.350 .000 & 915.000 \\
B & Model SP50-18P & 50 & 13.500 & 675.000 & 600.000 \\
\hline
\end{tabular}

Menghitung output daya panel surya :

$$
\mathrm{P}_{\mathrm{G}}=\mathrm{A}_{\mathrm{G}} \times \mathrm{S} \times \mathrm{t} \times \eta
$$

Model CPS SP100-18P Mono \& Polycrystalline (atau setara)

$$
\mathrm{P}_{\mathrm{G}}=0,67 \mathrm{~m}^{2} \times(3,07 \mathrm{jam} / \mathrm{hari}) \times\left(\mathrm{Kw} / \mathrm{m}^{2}\right) \times 0,175
$$$$
\mathrm{P}_{\mathrm{G}}=0,360(\mathrm{Kw} / \mathrm{hari})
$$

Model CPS SP50-18P Mono \& Polycrystalline (atau setara)

$$
\mathrm{P}_{\mathrm{G}}=0,36 \mathrm{~m}^{2} \times(3,07 \mathrm{jam} / \mathrm{hari})\left(\mathrm{Kw} / \mathrm{m}^{2}\right) \times 0,175
$$$$
\mathrm{P}_{\mathrm{G}}=0,194(\mathrm{Kw} / \mathrm{hari})
$$

Tabel 7. Kapasitas Total Panel Surya

\begin{tabular}{ccccc}
\hline No. & Jenis / Type & $\begin{array}{c}\text { Output } \\
\text { Daya PV } \\
\text { (Kw/hari) }\end{array}$ & $\begin{array}{c}\text { Jumlah PV } \\
\text { (Set) }\end{array}$ & $\begin{array}{c}\text { Kapasitas } \\
\text { Total PV } \\
\text { (Kw) }\end{array}$ \\
\hline A & Model SP100-18P & 0,360 & 1501 & 540,19 \\
B & Model SP50-18P & 0,194 & 417 & 81,03 \\
\hline
\end{tabular}

Menghitung pemakaian listrik seperti menghitung kapasitas angkut bus umum. Kapasitas angkut bus umum adalah 50 person namun dalam sehari bisa PP berarti bisa mengankut 500 person per hari. Namun apabila dipaksakan kapasitasnya 100 person per sekali angkut tentu overload. Kasusnya sama dengan kapasitas daya listrik apabila sekali pakai dalam waktu bersamaan 1.150.000,00 Watt maka listrik akan Down karena overload. Namun karena pemakaian, pendingin, lampu penerangan, alat kesehatan dan sarana lain bergantian sesuai kebutuhan maka didapatkan kebutuhan total 8.000.000 Watt/hari.

Kapasitas listrik dari panel surya yang bisa dipasang menghasilkan daya 621,49 KVA atau 621.000 watt sudah bisa menanggung seluruh kebutuhan listrik rumah sakit dan mandiri. Listrik yang direncanakan awal proyek adalah 500 KVA menggunakan 3 trafo PLN. Luas selubung atap tersedia 2.306,94 m2 yang dimanfaatkan $1.156 \mathrm{~m} 2$ berkisar $50,12 \%$ dari luasan selubung atap yang ada.

Jumlah unit PV disesuiakan dengan kebutuhan total daya opersional gedung dan alat. Luas PV plotkan dengan luas selubung atap efektif yang tersedia untuk ditempati PV tersebut.

Kemudian bisa dihitung biaya awal dari panel surya se-

\begin{tabular}{|c|c|c|c|c|}
\hline No. & Jenis / Type & $\begin{array}{c}\text { Jumlah } \\
\text { (Modul) }\end{array}$ & $\begin{array}{c}\text { Harga satuan } \\
\text { Incl. Pasang } \\
\text { (Rp.) }\end{array}$ & $\begin{array}{l}\text { Total Harga } \\
\quad \text { (Rp.) }\end{array}$ \\
\hline A & Model SP100-18P & 1.501 & 2.265 .000 & 3.399 .122 .687 \\
\hline B & Model SP50-18P & 417 & 1.275 .000 & 531.503 .731 \\
\hline
\end{tabular}
perti terlihat pada Tabel 8.

Tabel 8. Biaya Awal Panel Surya

Jumlah biaya awal

3.930 .626 .418

(c) Menghitung Investasi

Penilaian ekonomi baru-baru ini termasuk D Ádamo dkk. (2020) yang mengusulkan ekonomimodel berdasarkan nett present value (NPV) dan payback period (PBP) yang didiskon mengevaluasi kelayakan ekonomi sistem PV di bangunan umum [33].

Pembayaran kembali energy waktu untuk fasad PV multi warna adalah 8,1 tahun, yang berkurang $35 \%$ menjadi 5,3 tahun saat diganti kaca selubung hujan di fasad yang ada, menyisakan 25 tahun untuk kelebihan pembangkit listrik [34].Penerapan sistem fotovoltaik pada bangunan membutuhkan analisis yang mendalam untuk membuatnya opsi energi berkinerja baik dalam hal efisiensi energi, masalah ekonomi, efek spasial, dan juga nilai estetika bangunan, komponennya, dan bahkan tata letak plot [35].

Menghitung harga investasi di tahun ke 8 (delapan) masa operasional dengan menggunakan :

$\mathrm{F}=\mathrm{P} \times(1+\mathrm{i})^{\mathrm{n}}$

$\mathrm{F}=$ Future Sum of Money; $\mathrm{P}=$ Present Sum of Money

$\mathrm{i}=$ Interest Rate $; \quad \mathrm{n}=$ number of Interest Periods

Sumber : Buku Engineering Economic Analysis hal. 51

Bila harga awal investasi $\mathrm{P}=$ Rp. 3.930.626.418; $\mathrm{i}=10 \%$

; $\mathrm{n}=8$ tahun

$\mathrm{F}=$ Rp. 3.930.626.418 x $(1+0,1)^{8}=$ Rp. 8.425.646.806

Biaya awal $=$ Rp. 8.425.646.806/(12x8) bulan 


$$
=\text { Rp. 87.767.154/bulan }
$$

Setelah biaya awal didapat maka dihitung nilai investasi dalam masa 8 tahun, seperti terlihat pada Tabel 9.

Tabel 9. Nilai Investasi Panel Surya

\begin{tabular}{|c|c|c|}
\hline \multicolumn{2}{|l|}{ Biaya Investasi } & Rp. 3.930.626.418 \\
\hline Depresiasi & 8 tahun & \\
\hline \multicolumn{2}{|l|}{ Unit Cost / bulan } & Rp. 87.767.154 \\
\hline \multicolumn{3}{|l|}{ Operational Cost } \\
\hline \multicolumn{3}{|l|}{ Biaya Listrik } \\
\hline Biaya per KwH & $\operatorname{Rp} 605$ & \\
\hline $\begin{array}{l}\text { A Total Konsumsi/hari } \\
(\mathrm{KwH})\end{array}$ & 0 & \\
\hline $\begin{array}{l}\text { Total Biaya } \\
\text { Listrik/hari } \\
\text { Total Biaya }\end{array}$ & 0 & \\
\hline Listrik/bulan & & 0 \\
\hline
\end{tabular}

Biaya Operator

B No. Operator 2 Orang

Gaji/bulan Rp 4.250 .000

Total gaji/bulan

$\operatorname{Rp} 8.500 .000$

Biaya Maintenance/Consumable

C Biaya maintenance Rp78.612.528

Biaya

maintenance/bulan

Rp78.612.528

Uji Berkala

D Uji

per tahun

Biaya per bulan

0

Total Biaya Operasional /bulan

$(\mathrm{A}+\mathrm{B}+\mathrm{C}+\mathrm{D})$

$\operatorname{Rp} 87.112 .528$

Total Biaya per Bulan (+Depresiasi)

Rp 174.879 .683

Total biaya sampai dengan 8 tahun

Rp 16.788.449.528

Pembayaran kembali Instalasi Pembangkit Listrik Tenaga Surya (PLTS)

Pemakaian listrik/hari (Kwh) 8.000

$\begin{array}{ll}\text { Biaya/Kwh } & \text { Rp } 605 \\ \text { Biaya/hari } & \text { Rp } 4.840 .000\end{array}$

Total biaya pemakaian listrik per bulan Rp 145.200 .000

Penghematan per tahun $\quad$ Rp 1.742.400.000

Payback Period = Jumlah Investasi/Penghematan per tahun.

Payback Period $=$ Rp 16.788.449.528/ Rp 1.742.400.000
Payback Period $=9,64$ tahun $\approx 9$ tahun 7 bulan

\section{Instalasi Pemusnah Limbah B3}

Fungsi utama dari pemusnah limbah adalah memusnahkan bahan limbah Bahan Berbahaya dan Beracun (B3), fungsi tambahannya mendukung program pemerintah meringankan beban lingkungan, mengurangi ketergantungan ke pihak ketiga dan sebagai sumber penghasilan bagi rumah sakit. Karena rumah sakit bisa menghemat pengeluaran yang cukup besar untuk limbah tersebut dan apabila produksi limbah sendiri kurang dari kapasitas mesin yang ada bisa menerima jasa pemusnahan limbah dari fasilitas kesehatan lainnya.

Perbandingan biaya system pemusnahan limbah yang ada pada saat ini seperti terlihat pada Tabel 10. Dapat dilihat bahwa metoda microwave lebih ekonomis.

Tabel 10. Biaya Proses Musnah Limbah B3 per Kg [36]

\begin{tabular}{lccc}
\hline Method & $\begin{array}{c}\text { Capacity } \\
\text { (kg/hour) }\end{array}$ & $\begin{array}{c}\text { Capital Cost } \\
\text { (US\$ } \$ \text { 1000) }\end{array}$ & $\begin{array}{c}\text { Operating } \\
\text { Cost } \\
\text { (US\$/kg) }\end{array}$ \\
\hline Autoclave & $23-3.600$ & $30-1780$ & $0.13-0.36$ \\
$\begin{array}{l}\text { Chemical } \\
\text { Treatment } \\
\text { Microwave }\end{array}$ & $11-6800$ & $20-890$ & $0.15-2.20$ \\
Incineration & $23-410$ & $70-710$ & $0.10-0.42$ \\
\hline a high technology incinerators with air pollution control
\end{tabular}

Peneliti mempelajari spesifikasi teknik dari produk yang ada di pasar dan sangat mungkin untuk di aplikasikan di rumah sakit yang sedang ditinjau. Layak tidaknya kita pertimbangkan dari segi green process dan green result nya serta investasinya layak dihitung dengan Life cycle Cost Analysis.

Menghitung harga investasi di tahun ke 8 masa operasional dengan menggunakan :

$$
\mathrm{F}=\mathrm{P} \times(1+\mathrm{i})^{\mathrm{n}}
$$

Bila harga awal investasi $\mathrm{P}=$ Rp. 4.383.000.000; $\mathrm{i}=10 \%$; $\mathrm{n}=8$ tahun

$$
\begin{aligned}
\mathrm{F} & =\text { Rp. } 4.383 .000 .000 \times(1+0,1)^{8} \\
& =\text { Rp. 9.395.349.754 } \\
\text { Biaya awal } & =\text { Rp. 9.395.349.754/(12x8) bulan } \\
& =\text { Rp. 97.868.227/bulan }
\end{aligned}
$$

Setelah biaya awal didapat maka dihitung nilai investasi dalam masa 8 tahun, seperti terlihat pada Tabel 11 Pembayaran Kembali investasi Pemusnah Limbah B3 
Total Limbah/hari $(\mathrm{Kg}) \quad 400$

$\begin{array}{ll}\text { Biaya/kg } & \text { Rp } 25.000 \\ \text { Biaya/hari } & \text { Rp } 10.000 .000\end{array}$

Total cost pemusnahan B3 per bulan Rp 300.000.000

Penghematan per tahun Rp 3.600.000.000

Payback Period = Jumlah Investasi / Penghematan per tahun.

Payback Period $=$ Rp 15.408.533.754/ Rp 3.600.000.000

Payback Period $=4,28$ Tahun $\approx 4$ Tahun 3 Bulan.

Tabel 11. Nilai investasi Pemusnah Limbah B3

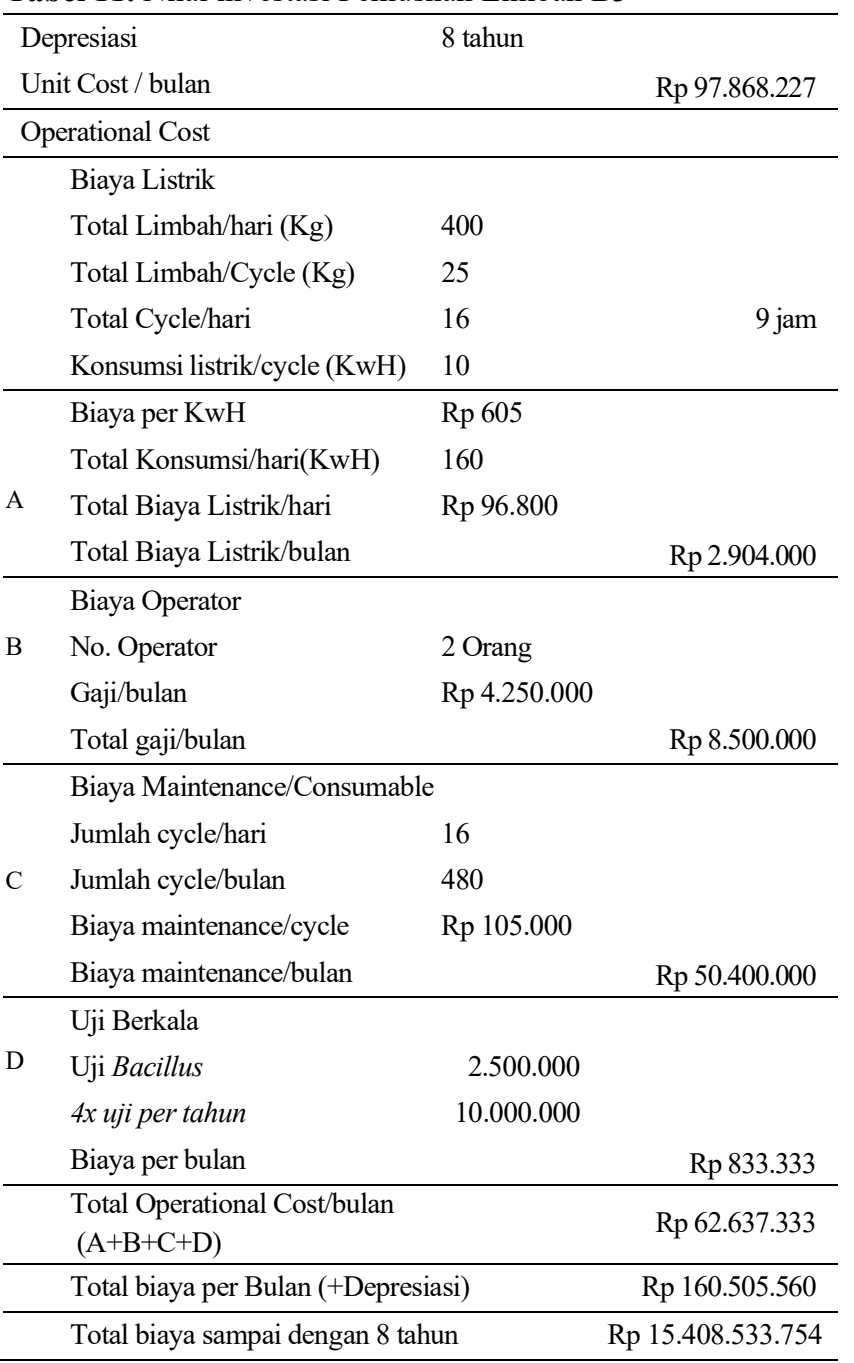

Tanpa menghitung nilai residual (nilai sisa) bahwa investasi sebagai penambahan fungsi untuk pemusnah limbah B3 ini bisa ramah lingkungan dan menguntungkan dari segi investasi.
Dengan pembayaran kembali yang pendek ini semoga bisa mendorong pemilik proyek ataupun investor untuk menanamkan investasinya dibidang pemusnah limbah baik untuk rumah sakit maupun pelayanan kesehatan lainnya. Karena masih banyak rumah sakit dan sarana kesehatan yang tidak transfaran dalam laporan kemana limbah B3 dimusnahkan karena memang harganya yang tinggi.

Pemusnah limbah ini disamping bisa mendatangkan keuntungan juga membantu meringankan beban lingkungan yang saat ini begitu berat dan over capasity. Dengan sarana pemusnah limbah ini bisa menjadi nilai tambah rumah sakit dalam menaikkan kelasnya maupun mempertahankan kelas yang sudah dicapai.

\section{Simpulan}

Berdasarkan penelitian dari Rencana Anggaran Biaya (RAB), spesifikasi teknis dan gambar rencana maka pada proses pemilihan material Green dan proses Life Cycle Cost maka dapat disimpulkan sebagai berikut:

1. Pengembalian modal untuk pengadaan pembangkit listrik tenaga surya ini membutuhkan waktu $=9,64$ Tahun $\approx 9$ Tahun 7 Bulan untuk Break Event Point (BEP). Dengan tanpa menghitung nilai residual (nilai sisa), bahwa investasi sebagai penambahan fungsi Pembangkit Listrik Tenaga Surya (PLTS) ini bisa ramah lingkungan dan menguntungkan dari segi investasi.

2. Pengembalian modal untuk pengadaan pemusnah limbah B3 $=4,28$ Tahun $\approx 4$ Tahun 3 Bulan untuk BEP. Dengan tanpa menghitung nilai residual (Nilai sisa) bahwa investasi sebagai penambahan fungsi untuk pemusnah limbah B3 ini bisa ramah lingkungan dan menguntungkan dari segi investasi.

3. Berdasarakan hasil analisis tersebut hipotesis bahwa peningkatan kinerja biaya dengan metode Lifecycle Cost Analysis (LCCA) pada proyek Green Hospital, terbukti. Hubungan Value Engineering dan LCCA dengan Green Hospital, adalah untuk memecahkan beberapa masalah dalam membentuk bangunan green yaitu cost overrun perencanaan maupun pelaksanaan dan prospek investasi yang layak dan menguntungkan.

\section{Daftar Pustaka}

[1] F. J. Montiel-Santiago, M. J. Hermoso-Orzáez, and J. Terrados-Cepeda, "Sustainability and Energy Efficiency: BIM 6D. Study of the BIM Methodology Applied to Hospital Buildings. Value of Interior Lighting and Daylight in Energy Simulation," Sustainability, vol. 12, no. 14, p. 5731, 2020.

[2] Y. Han, T. He, R. Chang, and R. Xue, "Development 
Trend and Segmentation of the US Green Building Market: Corporate Perspective on Green Contractors and Design Firms," J. Constr. Eng. Manag., vol. 146, no. 11, p. 05020014, 2020.

[3] M. Spišáková, P. Mésároš, and T. Mandičák, "Construction Waste Audit in the Framework of Sustainable Waste Management in Construction Projects-Case Study," Buildings, vol. 11, no. 2, p. 61, 2021.

[4] K. J. Mejía, M. D. M. Barbero-Barrera, and M. R. Pérez, "Evaluation of the impact of the envelope system on thermal energy demand in hospital buildings," Buildings, vol. 10, no. 12, pp. 1-17, 2020.

[5] S. Atabay, A. Pelin Gurgun, and K. Koc, "Incorporating BIM and Green Building in Engineering Education: Assessment of a School Building for LEED Certification," Pract. Period. Struct. Des. Constr., vol. 25, no. 4, p. 04020040, 2020.

[6] N. Campion, C. L. Thiel, J. Focareta, and M. M. Bilec, "Understanding Green Building Design and Healthcare Outcomes: Evidence-Based Design Analysis of an Oncology Unit," J. Archit. Eng., vol. 22, no. 3, p. 04016009, 2016.

[7] B.-G. Hwang, L. Zhu, Y. Wang, and X. Cheong, "Green Building Construction Projects in Singapore," Proj. Manag. J., vol. 48, no. 4, pp. 67-79, 2017.

[8] V. Basten, I. Crévits, Y. Latief, and M. A. Berawi, "Conceptual development of cost benefit analysis based on regional, knowledge, and economic aspects of green building," Int. J. Technol., vol. 10, no. 1, pp. 81-93, 2019.

[9] R. Doczy and Y. AbdelRazig, "Green Buildings Case Study Analysis Using AHP and MAUT in Sustainability and Costs," J. Archit. Eng., vol. 23, no. 3, p. 05017002 , 2017.

[10] P. Miraj, M. A. Berawi, G. Gunawan, and A. E. Husin, "Conceptual Design of Sunda Strait Bridge Using Value Engineering Approach Conceptual Design of Sunda Strait Bridge Using Value Engineering Approach,” no. December, 2012.

[11] T. C. Marrana, J. D. Silvestre, J. De Brito, and R. Gomes, "Lifecycle Cost Analysis of Flat Roofs of Buildings," J. Constr. Eng. Manag., vol. 143, no. 6, 2017.

[12] A. E. Husin, M. A. Berawi, S. Dikun, T. Ilyas, and A. R. B. Berawi, "Forecasting demand on mega infrastructure projects: Increasing financial feasibility," Int. J. Technol., vol. 6, no. 1, pp. 73-83, 2015.

[13] M. Basto and J. M. Pereira, "An SPSS R-menu for ordinal factor analysis,” J. Stat. Softw., vol. 46, no. 4,
2012.

[14] A. Naidenov and A. Naidenov, "Using SPSS for Process Quality Control - A Critical Review Using SPSS for Process Quality Control - A Critical Review," no. FEBRUARY 2014, 2015.

[15] T. Subramani and S. R. Rajiv, "Productivity Of Industry Using SPSS,” vol. 5, no. 5, pp. 239-250, 2016.

[16] D. Lakens and A. Caldwell, "Simulation-Based PowerAnalysis for Factorial ANOVA Designs," pp. 1-11, 2019.

[17] S. Moradi, K. Kähkönen, and K. Aaltonen, "Project managers' competencies in collaborative construction projects," Buildings, vol. 10, no. 3, pp. 1-17, 2020.

[18] H. Liu, "Evaluating Construction Cost of Green Building Based on Life- cycle Cost Analysis: An empirical analysis from Nanjing, China," vol. 9, no. 12, pp. 299 306, 2015.

[19] H. T. T. Le, V. Likhitruangsilp, and N. Yabuki, “A BIMintegrated relational database management system for evaluating building life-cycle costs," Eng. J., vol. 24, no. 2, pp. 75-86, 2020.

[20] H. Huang, Y. Huang, and Y. Perng, "Evaluating critical criteria for green hospital buildings Evaluating critical criteria for green hospital buildings," 2020.

[21] A. Hatami and G. Morcous, "Deterministic and Probabilistic Lifecycle Cost Assessment: Applications to Nebraska Bridges," J. Perform. Constr. Facil., vol. 30, no. 2, 2016.

[22] P. Samani, J. Gregory, V. Leal, A. Mendes, and N. Correia, "Lifecycle Cost Analysis of Prefabricated Composite and Masonry Buildings: Comparative Study," J. Archit. Eng., vol. 24, no. 1, pp. 1-11, 2018.

[23] K. Khun-Anod and C. Limsawasd, "Pre-project planning process study of green building construction projects in Thailand," Eng. J., vol. 23, no. 6, pp. 67-81, 2019.

[24] M. A. Berawi et al., "Developing conceptual design of high speed railways using value engineering method: Creating optimum project benefits," Int. J. Technol., vol. 6, no. 4, pp. 670-679, 2015.

[25] A. Darvish, S. R. Eghbali, G. Eghbali, and Y. G. Mahlabani, "The Effects of Building Glass Façade Geometry on Wind Infiltration and Heating and Cooling Energy Consumption,” vol. 11, no. November 2019, pp. 235-247, 2020.

[26] J. Lee, "Value Engineering for Defect Prevention on Building Façade," vol. 144, no. Beasley 2014, pp. 1-8, 2018.

[27] B. A. Rock, “Comparing building surfaces' orientations 
to optimize solar energy collection," J. Green Build., vol. 15, no. 2, pp. 3-28, 2020.

[28] D. Satola, M. Röck, A. Houlihan-Wiberg, and A. Gustavsen, "Life cycle GHG emissions of residential buildings in humid subtropical and tropical climates: Systematic review and analysis," Buildings, vol. 11, no. 1, pp. 1-36, 2021.

[29] K. Joseph, A. Selvam, and J. W. C. Wong, "Healthcare waste management," Sustain. Solid Waste Manag., pp. 477-510, 2016.

[30] P. R. Rout, P. Bhunia, A. Ramakrishnan, R. Y. Surampalli, T. C. Zhang, and R. D. Tyagi, "Sustainable hazardous waste management/treatment: Framework and adjustments to meet grand challenges," Sustain. Solid Waste Manag., pp. 319-364, 2016.

[31] V. Bertolini, “APLIKASI VALUE ENGINEERING PADA PROYEK PEMBANGUNAN GEDUNG ( Studi Kasus Hotel Grand Banjarmasin )," J. IPTEK, vol. 20, no. 2, p. 53, 2016.

[32] C. Basu, V. K. Pau, and M. G. M. Syal, "Performance indicators for energy efficiency retrofitting in multifamily residential buildings," J. Green Build., vol. 14, no. 2, pp. 109-136, 2019.

[33] C. S. Guno, C. B. Agaton, R. O. Villanueva, and R. O. Villanueva, "Optimal investment strategy for solar pv integration in residential buildings: A case study in the philippines," Int. J. Renew. Energy Dev., vol. 10, no. 1, pp. 79-89, 2021.

[34] J. Park, D. Hengevoss, and S. Wittkopf, "Industrial databased life cycle assessment of architecturally integrated glass-glass photovoltaics," Buildings, vol. 9, no. 1, pp. 119, 2018.

[35] P. Filipek, "Investigation of the E ff ective Use of Photovoltaic," 2020.

[36] L. F. Diaz et al., Solid waste management, Volume 1. 2005. 